\title{
Climatic Variation at Thumba Equatorial Rocket Launching Station, India
}

\author{
K. V. S. Namboodiri, P. K. Dileep, and Koshy Mammen \\ Meteorology Facility, Thumba Equatorial Rocket Launching Station (TERLS), Vikram Sarabhai Space Centre (VSSC), \\ Indian Space Research Organization, Thiruvananthapuram 695 022, India
}

Correspondence should be addressed to K. V. S. Namboodiri; sambhukv@yahoo.com

Received 22 June 2013; Accepted 25 September 2013

Academic Editors: A. V. Eliseev and E. Paoletti

Copyright (c) 2013 K. V. S. Namboodiri et al. This is an open access article distributed under the Creative Commons Attribution License, which permits unrestricted use, distribution, and reproduction in any medium, provided the original work is properly cited.

\begin{abstract}
Long-term (45 years) diversified surface meteorological records from Thumba Equatorial Rocket Launching Station (TERLS), India, were collected and analysed to study the long-term changes in the overall climatology, climatology pertained to a particular observational time, mean daily climatology in temperature, inter-annual variability in temperature, interannual variability in surface pressure, and rainfall for the main Indian seasons-South West and North East monsoons and inter-annual mean monthly anomaly structure in temperature. Results on various analyses show strong and vivid features contributed by climate change for this South Peninsular Indian Arabian Sea Coastal Station, and this paper may be a first time venture which discusses climate change imparted perturbations in several meteorological parameters in different time domains, like a specific time, daily, monthly, and interannually over a station. Being a coastal rocket launching station, climatic change information is crucial for long-term planning of its facilities as well as for various rocket range operational demands.
\end{abstract}

\section{Introduction}

Climate change refers to a statistically strong and significant variation in either the average state of the climate or in its variability, persisting for an extended period, typically in decades or longer. Short-period oscillations are statistically insignificant in the scenario of long-term climate change context. Climate change may be due to natural internal processes on earth (atmospheric, seismic, volcanic, and oceanic), external forces (variation in solar activity, rotation and revolution of earth), and more recently anthropogenic activities. It is now well established that anthropogenic activities cause intensification of the greenhouse effect and thereby contribute to the climate change. The paper by Oreskes [1] highlighted the listings in the ISI database on climate change from several abstracts published in refereed scientific journals between 1993 and 2003.

In India, the first time document on the concern of greenhouse effect and possible mitigation measures was published in the Science Reporter, CSIR, by Ayyar [2]. Several papers were published in a special session in Current
Science (volume 90, 2006) focussing the concerns over the socioeconomic and scientific aspects attributed to climate change on Indian scenario. To develop high-resolution climate change simulations over the Indian region, Providing Regional Climates for Impact Studies (PRECIS) modelling system was applied [3], and it was observed that the warming is monotonously widespread over India with substantial spatial differences in the projected rainfall changes.

Different data sets have been used in order to examine the monotonic change in the level of global temperature by various investigators [4-7]. From the diversified methodologies adopted, it is observed that the global surface temperature has risen by $0.74^{\circ} \mathrm{C}$ with an error of $\pm 0.18^{\circ} \mathrm{C}$ when estimated by a linear trend over the last 100 years (1906-2005) and $0.07^{\circ} \mathrm{C} \pm 0.02^{\circ} \mathrm{C}$ per decade. An executive summary is made available by Solomon et al. [8] on climate change in the fourth assessment report of the Intergovernmental Panel on Climate Change (IPCC). Climate change features are local or regional highly influenced by agricultural practices, urbanisation, heat island effect, changing irrigation, aerosol modifications, desertification, deforestation, and decay processes of organic 
materials [9-14]. Long-term changes in maximum temperature, minimum temperature, and their range have been analyzed over two stations in Cyprus by Price et al. [15] who established a reduction in range and thereby a possibility in increased cloud cover and tropospheric aerosols. Recently seasonal variability in mean sea level pressure extremes over the 11 zones of India and adjoining sea area has been studied by Singh et al. [16].

In the present paper, features on surface climate change over Thumba Equatorial Rocket Launching Station (TERLS), a coastal station near the South tip of Peninsular India, are critically examined. TERLS was established as an international rocket launching station dedicated to the United Nations for conducting meteorological and sounding rocket experiments on the geomagnetic equator. Meteorology group, TERLS has one of the heaviest responsibilities in the range to cater (i) weather forecasting and data needs of sounding rocket launch operations (in planning, pad operations and launching), (ii) climatological briefing to working crews including scientists to plan experiments, (iii) Organise various met. Observations, (iv) processing, analyses, storage and retrieval of various met. data (Class I surface observatory, autoweather stations, sonic anemometers, $50 \mathrm{~m}$ micro meteorological flux tower facility, meteorological balloon launches, rocket chaff derived wind data) and provide the data for users demand. For the planning of a scientific mission, the variability of climate is very crucial and thereby the importance of the present study on the climate change perspective. Importance of weather factors affecting rocket operations can be found elsewhere in detail $[17,18]$. Steady increase in temperature anomaly at different levels in the troposphere over TERLS was investigated and documented in the Space research in India [19]. Joseph and Simon [20] have investigated weakening trend of the South West monsoon current through Peninsular India. Dash et al. [21] reported the decreasing frequency of monsoon depressions over the Indian region, and Krishnakumar et al. [22] have analysed significant decrease in South West monsoon rainfall while increase in post monsoon season over the whole Kerala State (also a meteorological subdivision), India. From the voluminous data bank, the present study analyses daily, monthly, seasonal, and interannual variability on different meteorological parameters based on both eye reading instruments and non-instrumental practices in cloud and visibility observations as per World Meteorological Organization (WMO) practices. Till the inception of long-term uninterrupted data collection through instrument-based cloud and visibility measurements, data collection from such noninstrumental means solely vested on conventional methods in surface meteorological observations adopted worldwide is to be accepted for a reasonable climatology extraction. The present work examines the imprints made by the climatic change on several meteorological parameters in different time domains, like a specific time, daily, monthly, and interannually unlike the climate change associated variations on a single meteorological parameter like temperature or rainfall alone have dealt in most of the climatic change studies.

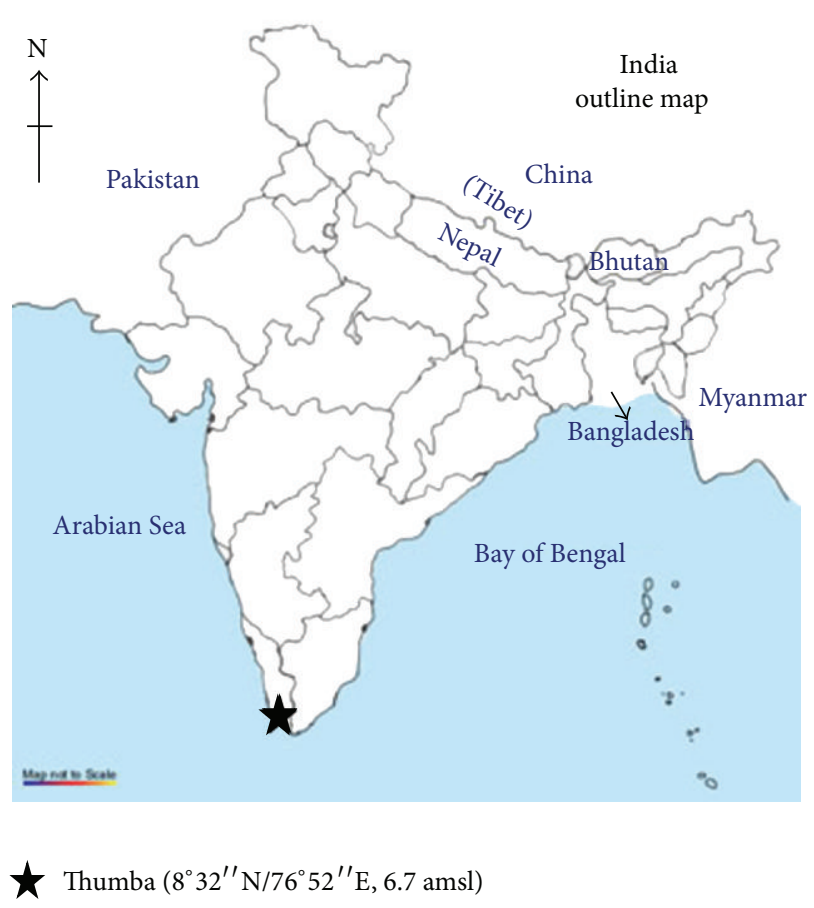

Figure 1: Location shows the class-I surface meteorological observatory at Thumba.

\section{Data and Methodology}

A class I surface meteorological observatory was established at TERLS $\left(8^{\circ} 32^{\prime \prime} \mathrm{N} / 76^{\circ} 52^{\prime \prime} \mathrm{E}, 6.7 \mathrm{amsl}\right)$ by India Meteorological Department (IMD) approximately $70 \mathrm{~m}$ away from the coastline of the Arabian Sea coast (Figure 1). TERLS is situated hardly $8 \mathrm{~km}$ West North West of Thiruvananthapuram, the capital city of the Kerala state of India. Various meteorological data from 0830 IST (Indian Standard Time, IST $=$ GMT $+0530 \mathrm{hr}$ ) observations for a period of 45 years (19642008), except for pressure where it is hourly data (19732008), are used in order to investigate changes encountered in meteorological parameters due to climate change. The data used are obtained from the following measurements at 0830 IST (1964-2008) namely, (i) maximum temperature (past $24 \mathrm{hr}$ reported at $0830 \mathrm{IST}$ ), (ii) minimum temperature (past $24 \mathrm{hr}$ reported at $0830 \mathrm{IST}$ ), (iii) past $24 \mathrm{hr}$ rainfall (reported at 0830 IST), (iv) dry-bulb temperature at 0830 IST, (v) wetbulb temperature at 0830 IST, (vi) relative humidity at 0830 IST, (vii) soil temperature at 0830 IST, (viii) non-instrumental eye observations on clouds and visibility at 0830 IST, (ix) wind speed and direction at 0830 IST, and (x) hourly surface pressure (1973-2008). Table 1 provides details on various instrumentation, exposure, maintenance, data span and the lowest and the highest in maximum absolute error values among various monthly statistics from 1964 to 2008.

The above mentioned 45 years of data have partitioned into two climatological slots of 30 years each, namely, 1964 to 1993 and from 1979 to 2008, respectively, called as past data for the former and present data for the later. Maximum absolute error values in the total data set (1962-2008) are the 


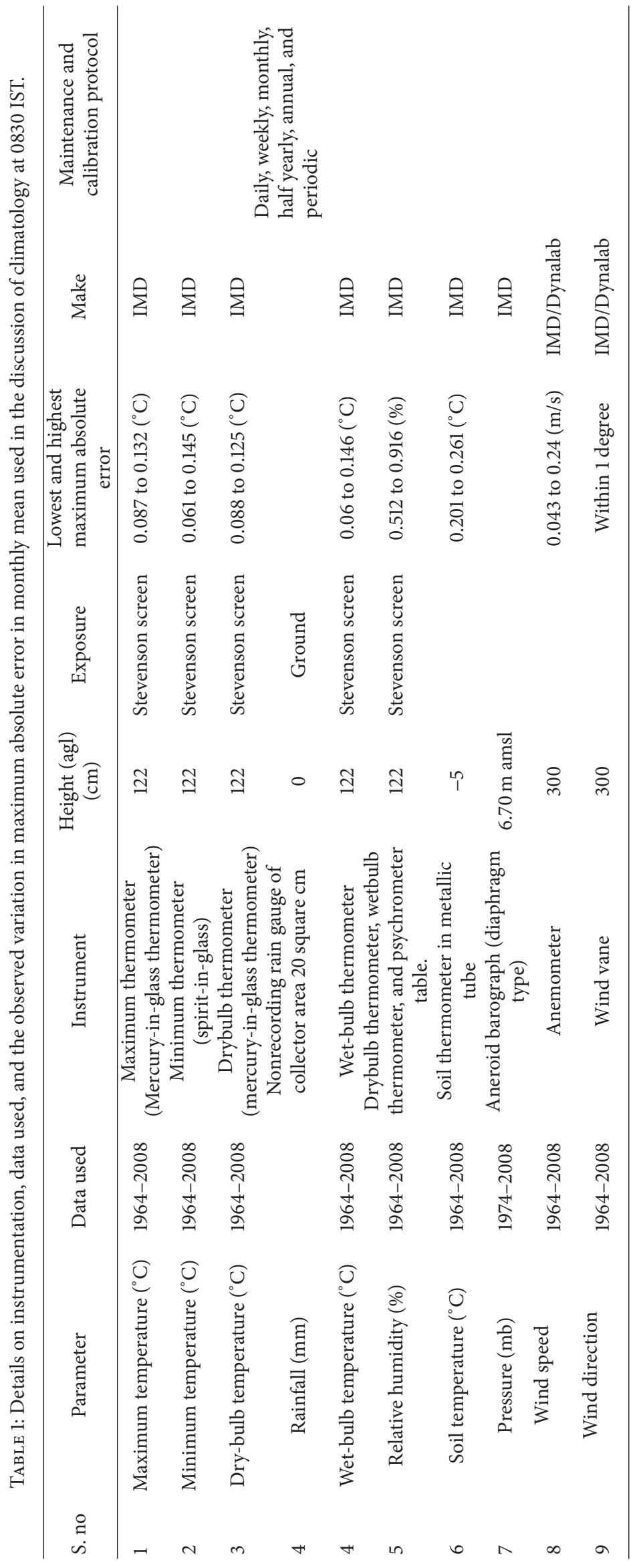


summation of errors [23] of past and present data sets. Individual error is computed as the ratio of standard deviation to the number of observations of a particular data set. Trenberth [24] has established the climate shift as a prominent upward trend in temperature after 1976. In order to include this observation influence, half portion (15 years) period from 1979 to 1993 is made common in the latter half of past data and in the former part of present data. The difference obtained among present data and past data has been represented as $\Delta$ in the discussions throughout. To see genuineness in findings attributed to climate change, $\Delta$ values are compared with absolute errors so as to see that $\Delta$ do not fall within absolute errors of corresponding meteorological parameters.

\section{Results and Discussion}

3.1. $\Delta$ Climatology of the Past $24 \mathrm{hr}$ Observations. Maximum temperature, minimum temperature, and $24 \mathrm{hr}$ accumulated rainfall are the only 3 meteorological parameters registered at 0830 IST having effect of the past $24 \mathrm{hr}$ variability behaviour. Climatology for various parameters has been derived for past data and present data and presented in Tables 2, 3, 4, and 5 in which months that constitute the different seasons are mentioned. Derived $\Delta$ values are also incorporated in the above tables. Comparison between past data and present data maximum temperature climatology shows marked increase in present data climatology in relation to the past data counterpart, and thereby, positive values alone are observed in $\Delta . \Delta$ values vary from $+0.01^{\circ} \mathrm{C}$ in the North East monsoon (NE monsoon) month November to $+0.43^{\circ} \mathrm{C}$ in the preSouth West monsoon (SW monsoon) month May. The NE monsoon season comprises October and November, whereas the four months from June to September designate SW monsoon season, which are the main two Indian seasons. In minimum temperature, all $\Delta$ values are positive with maximum value in the winter month February with a value $+0.53^{\circ} \mathrm{C}$. The observations among maximum and minimum temperature climatology derived in past data and present data along with $\Delta$ values can infer that the minimum daily temperatures have generally increased at a larger rate than the maximum daily temperatures. Karl et al. [25] studied the possible cause of increased urbanisation effects and Rebetez, and Beniston [26] justified the result of increased cloud cover in the large increase in minimum temperature and small increase in maximum temperatures.

From each individual daily maximum and minimum temperature, mean daily temperatures ((maximum temperature + minimum temperature)/2) are computed and further derive the past data and present data climatologies of mean temperatures. Only positive $\Delta$ values are observed throughout the year, which clearly indicate that the temperature over this tropical coastal station is increasing. Temperature climatologies have shown the tropical monsoonal characteristic of two maxima and two minima in monthly variation.

The diurnal temperature range is calculated from individual maximum and minimum temperature value and calculated past data and present data temperature range climatologies. Range climatologies are featured by annual variation. The prominent feature of negative $\Delta$ values in range is seen, which shows that the difference between maximum temperature and minimum temperature in a day is decreasing. Also, the larger rate of increase in minimum temperatures than maximum temperatures results in these negative $\Delta$ values in the diurnal temperature range.

The rainfall $\Delta$ shows decrease in rainfall in present data for the summer months April and May. Well-marked negative $\Delta$ values of about $21 \mathrm{~mm}$ are observed in the SW monsoon months (June-August). An increase in rainfall activity is detected in the SW monsoon month September and in the NE monsoon months October and November (debted to monsoonal climate) with maximum value of $+36.50 \mathrm{~mm}$ in October. The station weather is dominated by convective mesoscale systems during the NE monsoon. Probably this investigation poses the doubt about whether such meso-scale weather phenomena like thunderstorm formations are on increasing trend during NE Monsoon and thereby an increase in $\Delta$.

3.2. Climatology of a Particular Observation at 0830 IST. Analyses are carried out on different parameters collected at 0830 IST. $\Delta$ in dry bulb temperature, wet bulb temperature, and dew point temperature obtained from the two climatologies show only positive values. It ranges from $+0.60^{\circ} \mathrm{C}$ in July to $+1.01^{\circ} \mathrm{C}$ in January for dry bulb temperature. Variations in $\Delta$ among the SW monsoon months are less in general for all the above three variables, even though a maximum value in $\Delta$ is observed in dry bulb temperature. The less variation of wet bulb and dew point temperatures may be as a result of moisture laden atmosphere during the period which imparts corresponding variations in the moisture parameters like wet bulb temperature and dew point temperature.

Station relative humidity values at 0830 IST show more than $70 \%$ throughout the year with maximum in SW monsoon of the order $89 \%$. Low negative values in $\Delta$ relative humidity are detected as the air becomes drier in present data compared to past. As the air is getting dried, both dew point and the wet bulb temperatures are supposed to show negative $\Delta$ values, but the feature is not detected. This may be inferred as the dry bulb temperature is the key parameter in elevating $\Delta$ values of both dew point and wet bulb temperatures, and the meagre relative humidity decrease in present data than past data is insignificant to impart $\Delta$ changes in dew point and wet bulb temperatures. Climatologies of $\mathrm{RH}$ also have shown two maxima and two minima, whereas the secondary minima around the NE monsoon is shallow in character.

Significant positive $\Delta$ values are observed among the two climatologies in soil temperature with a low value of $+0.99^{\circ} \mathrm{C}$ to a high of $+2.35^{\circ} \mathrm{C}$ in July and January, respectively. Perhaps the $\Delta$ increase observed in the winter months January and February may contribute reduction in radiational cooling which leads to a reduction in fog formation probability over the station. Soil temperature climatologies also have shown tropical monsoonal type with two maxima and minima.

Wind speed (both scalar and resultant) is decreased in present climatologies. Mathematically resultant wind speed shall be determined as the square root of the sum of the squares of zonal and meridional wind components. The encountered $\Delta$ values that rise to a maximum value of 


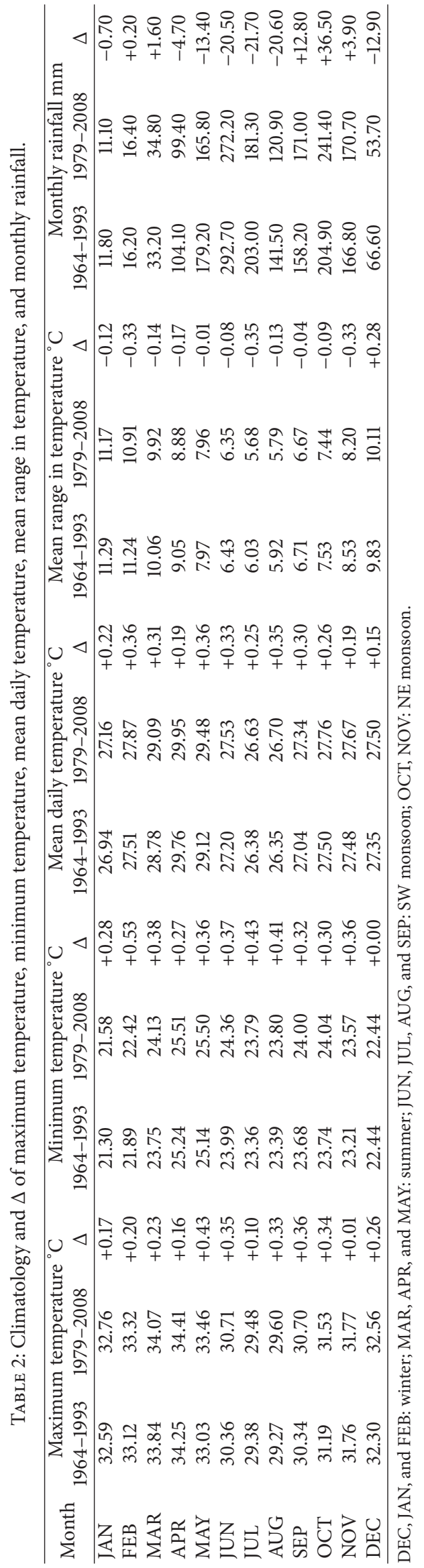




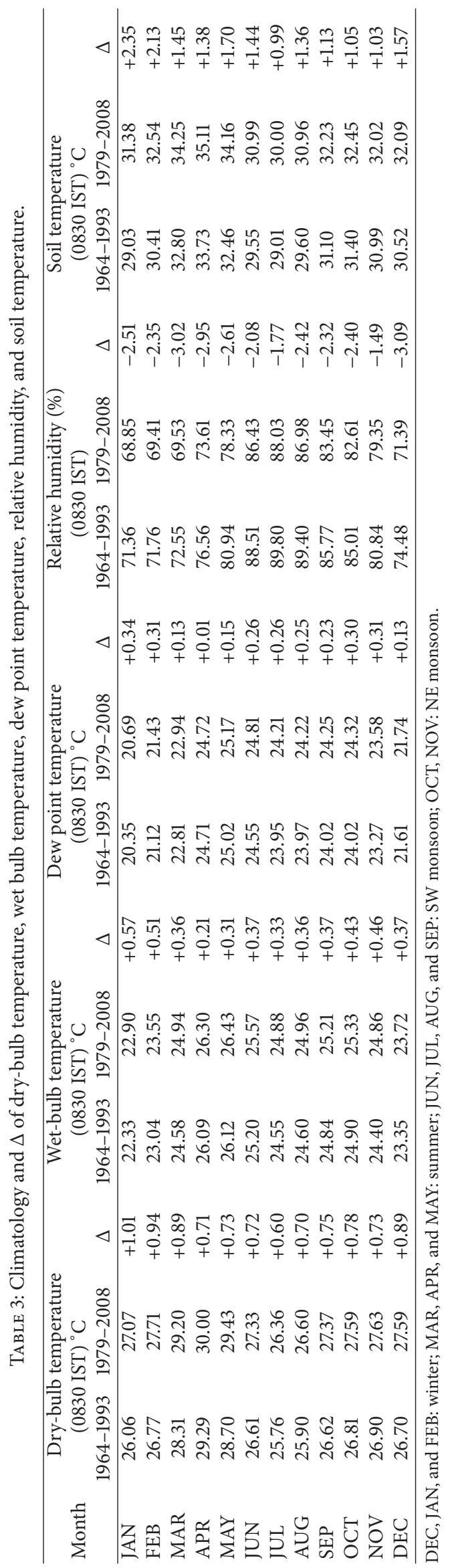




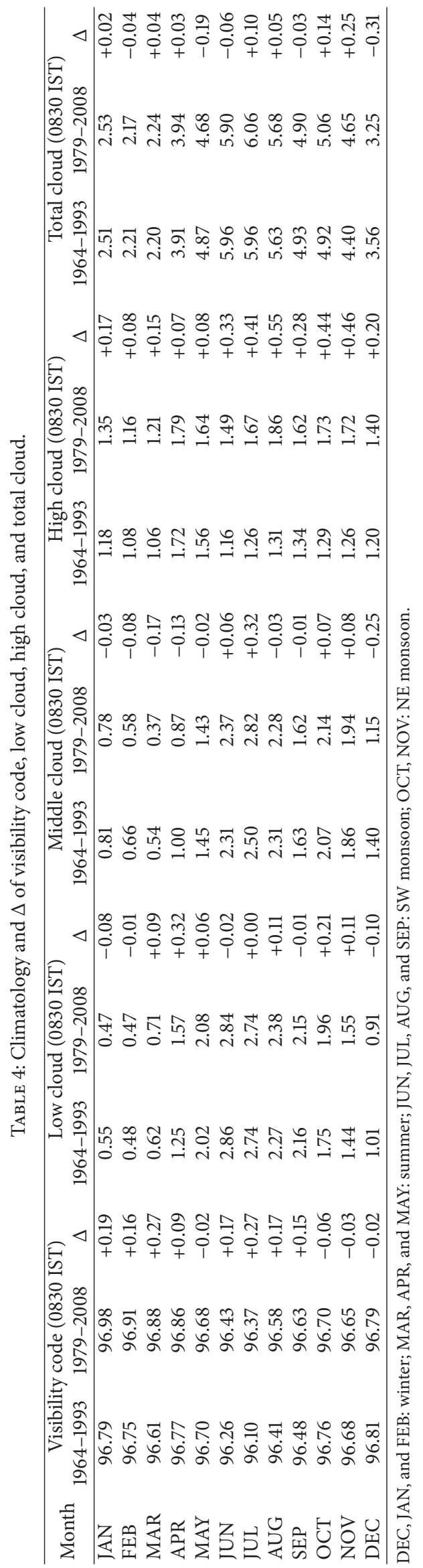


TABLE 5: Climatology and $\Delta$ of wind speed (scalar), wind speed (resultant), and wind steadiness factor.

\begin{tabular}{|c|c|c|c|c|c|c|c|c|c|}
\hline \multirow[t]{2}{*}{ Month } & \multicolumn{2}{|c|}{$\begin{array}{l}\text { Wind speed (scalar) } \\
\left(0830 \text { IST) } \mathrm{ms}^{-1}\right.\end{array}$} & \multirow[b]{2}{*}{$\Delta$} & \multicolumn{2}{|c|}{$\begin{array}{l}\text { Wind speed (resultant) } \\
\quad(0830 \mathrm{IST}) \mathrm{ms}^{-1}\end{array}$} & \multicolumn{4}{|c|}{$\begin{array}{l}\text { Wind steadiness factor } \\
\quad(0830 \text { IST })(\%)\end{array}$} \\
\hline & 1964-1993 & 1979-2008 & & & 1979-2008 & $\Delta$ & 1964-1993 & 1979-2008 & $\Delta$ \\
\hline JAN & 1.04 & 0.75 & -0.29 & 0.71 & 0.33 & -0.38 & 68.89 & 44.48 & -24.41 \\
\hline FEB & 1.07 & 0.81 & -0.26 & 0.73 & 0.38 & -0.35 & 67.95 & 47.36 & -20.59 \\
\hline MAR & 1.21 & 1.00 & -0.21 & 0.83 & 0.56 & -0.27 & 68.49 & 56.15 & -12.34 \\
\hline APR & 1.29 & 1.00 & -0.29 & 0.92 & 0.63 & -0.29 & 71.46 & 63.15 & -8.31 \\
\hline MAY & 1.45 & 1.04 & -0.41 & 1.14 & 0.75 & -0.39 & 78.40 & 72.44 & -5.96 \\
\hline JUN & 1.49 & 1.09 & -0.40 & 1.03 & 0.8 & -0.23 & 68.97 & 73.65 & +4.68 \\
\hline JUL & 1.68 & 1.35 & -0.33 & 1.15 & 0.94 & -0.21 & 68.08 & 69.60 & +1.52 \\
\hline AUG & 1.61 & 1.31 & -0.30 & 1.36 & 1.05 & -0.31 & 84.68 & 79.99 & -4.69 \\
\hline SEP & 1.57 & 1.10 & -0.47 & 1.17 & 0.81 & -0.36 & 74.57 & 74.06 & -0.51 \\
\hline OCT & 1.10 & 0.82 & -0.28 & 0.64 & 0.40 & -0.24 & 58.69 & 49.26 & -9.43 \\
\hline NOV & 0.97 & 0.74 & -0.23 & 0.49 & 0.23 & -0.26 & 50.29 & 31.17 & -19.12 \\
\hline DEC & 1.01 & 0.75 & -0.26 & 0.67 & 0.37 & -0.30 & 66.44 & 48.88 & -17.56 \\
\hline
\end{tabular}

DEC, JAN, and FEB: winter; MAR, APR, and MAY: summer; JUN, JUL, AUG, and SEP: SW monsoon; OCT, NOV: NE monsoon.

the order $0.5 \mathrm{~m} / \mathrm{s}$ are due to decrease in wind speeds in the present data climatology in comparison with past data climatology. Wind steadiness factor values at 0830 IST are computed as the ratio of mean resultant wind speed to mean scalar wind (average value of scalar wind speeds) expressed in $\%$, and the two slot climatologies are made. Wind steadiness factor is a general meteorological technique in order to derive the quantitative estimate of steadiness of wind direction [27]. The feature of losing controllability of blowing winds from a specific direction (computed from wind steadiness) as the demand of a particular season might be justified as a result of heat island effect of the very fast developing urbanisation hardly $8 \mathrm{~km}$ East South East of the observatory and the increasing vehicle populations and thereby drastic modifications in at 0830 IST observations which belong to land breeze prevalence over the station in the non-SW monsoonal months (up to a maximum of $20 \%$ decrease). Throughout the day, strong seabreeze is in prevalence in the SW monsoon months. Even in the SW monsoon which is dominantly associated with unidirectional wind flow, slight deteriorations in the steadiness of the wind directions have observed. Both the above observations brought out the phenomenal changes in the steadiness of offshore winds (land breeze) at 0830 IST during the non-SW monsoonal months at greater extend and onshore wind (sea breeze) at 0830 IST during the SW monsoon steadiness in smaller grades. The feature of very prominent decrease in direction steadiness in preset data to the past is clearly detected. As negative $\Delta$ dominance exists in the non-SW monsoon months where change over of land-sea breezes are so pronounced for the station, this observation may be further studied in order to check any possible modifications in the meso-scale meteorological phenomena like sea/land breeze, thunderstorms due to associated thermal and moisture environment changes.

Visibility and cloud climatologies are also studied. As these observational procedures are non-instrumental, the data is too subjective and quality observation is solely vested

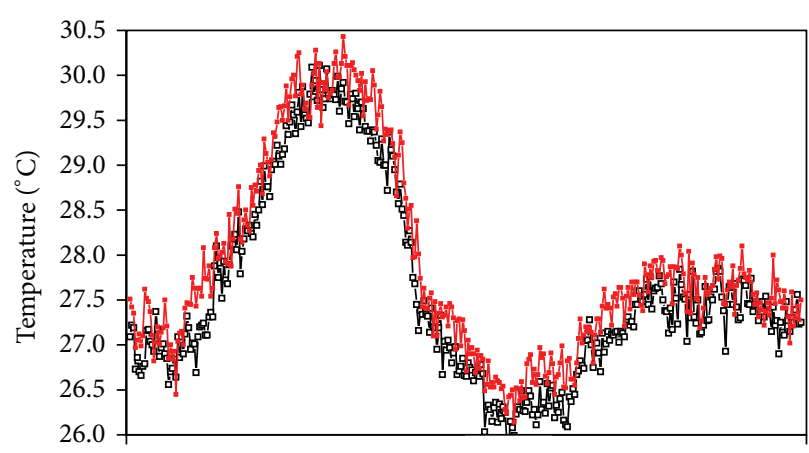

(a)

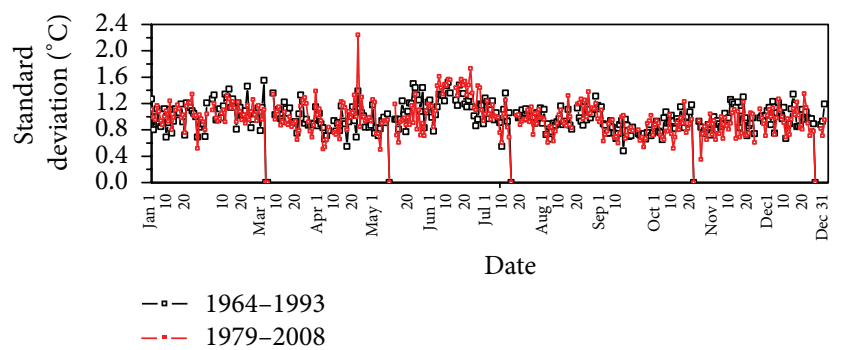

(b)

Figure 2: (a) Mean daily temperature climatologies in 1964-1993, 1979-2008, and their differences, along with (b) standard deviation of corresponding climatologies.

on the experience of the weather observer. The observation shows, better visibility codes in the present data climatology. A visibility code of 96 and above signifies that a well-defined object (like a mobile phone tower) at least $1 \mathrm{~km}$ far can be distinctly differentiable. Among various cloud climatology, dominant positive $\Delta$ values are existed in high clouds through out the year which may be pointed out as one of the reason for subdued albedo effect which enhances greenhouse effect, and 


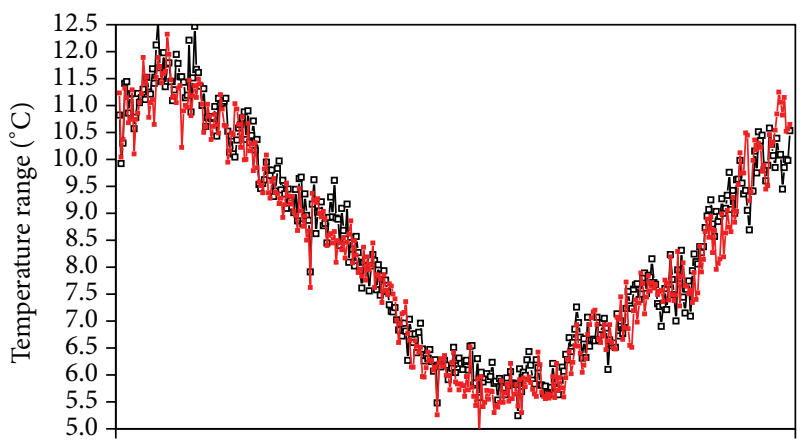

(a)

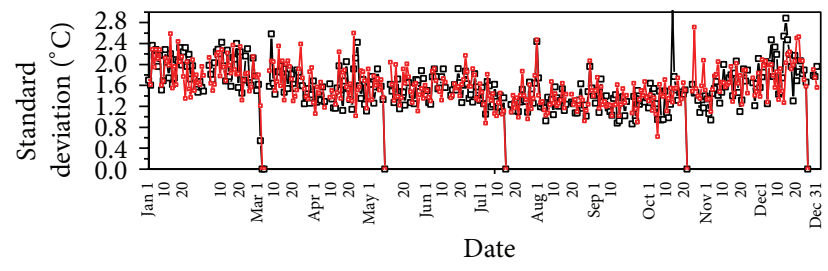

$-\square-1964-1993$

$-\cdot-1979-2008$

(b)

Figure 3: (a) Mean daily temperature range climatologies in 19641993, 1979-2008, and their differences, along with (b) standard deviation of corresponding climatologies.

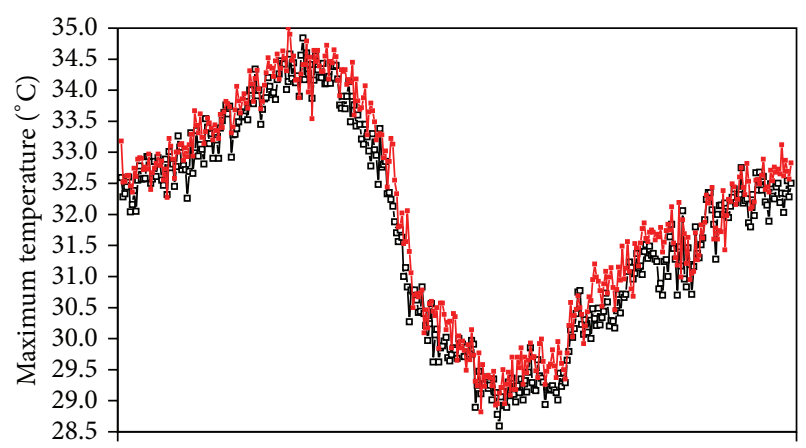

(a)

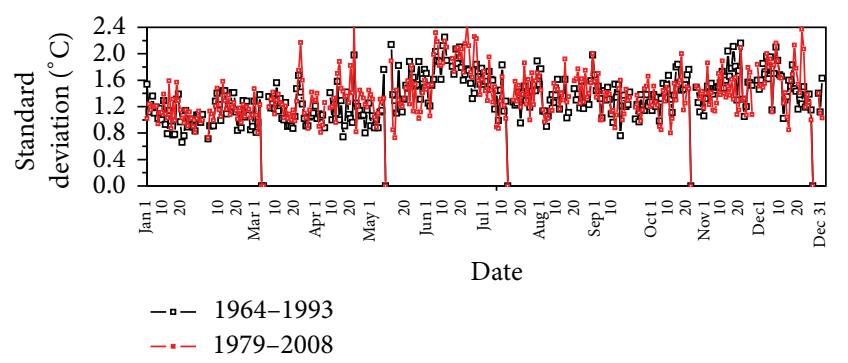

(b)

FIgURE 4: (a) Maximum daily temperature climatologies in 19641993, 1979-2008, and their differences, along with (b) standard deviation of corresponding climatologies.

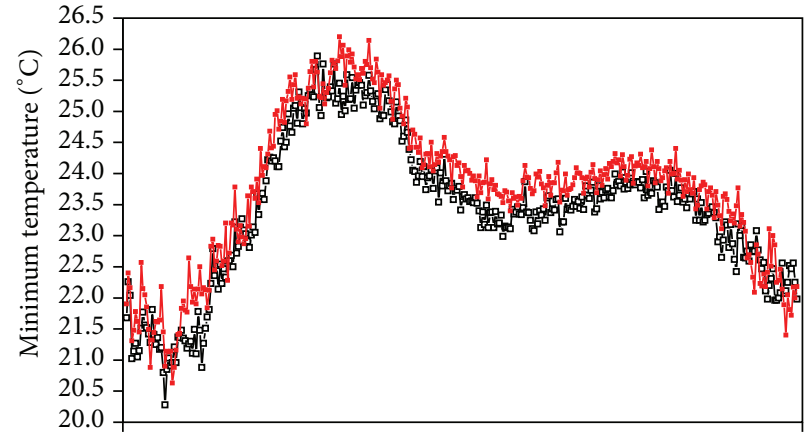

(a)

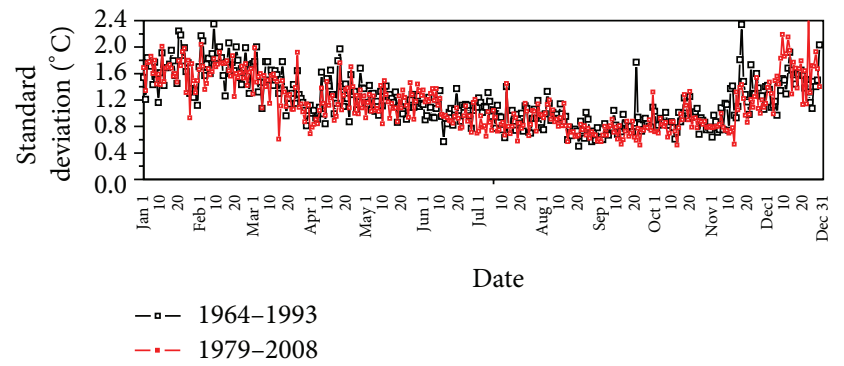

(b)

FIgURE 5: (a) Minimum daily temperature climatologies in 19641993, 1979-2008, and their differences, along with (b) standard deviation of corresponding climatologies.

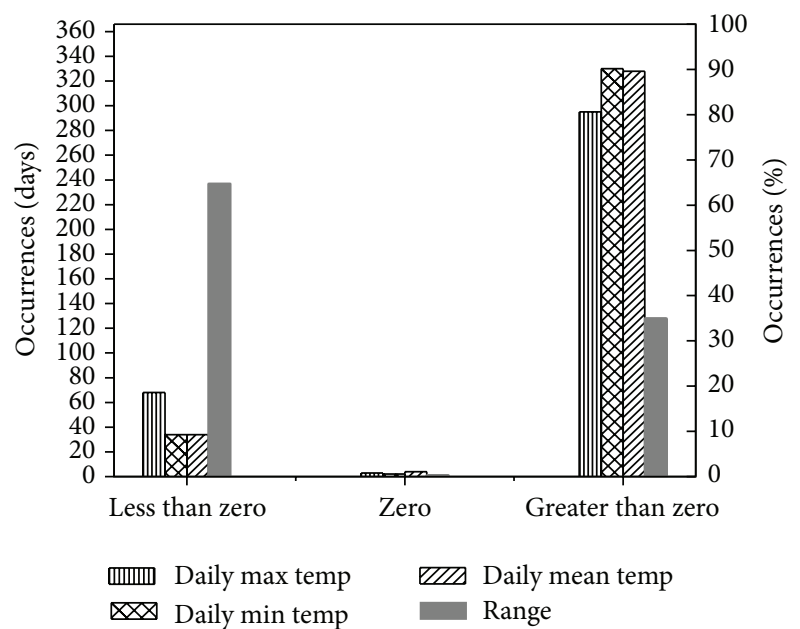

FIGURE 6: Difference statistics for 365 days between present data and past data on daily maximum, minimum, mean temperatures, and range in temperature within a day.

hereby surface temperature escalation. This may be the result of number of high cloud types ( $\mathrm{Ci}$ and $\mathrm{Cc}$ ) are less compared to the varieties of low and middle cloud types, which enables easy estimation for the observer while making counts on high clouds. The increase in high cloud climatology values in present data may be the result of increase in air traffic resulted contrails over the region which results an increase in cirrus cloud formations due to tropical dynamics unlike 


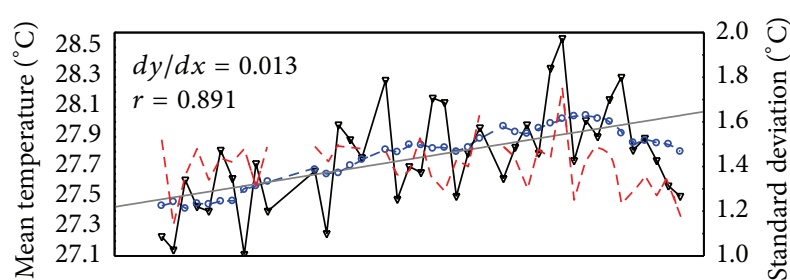

(a)

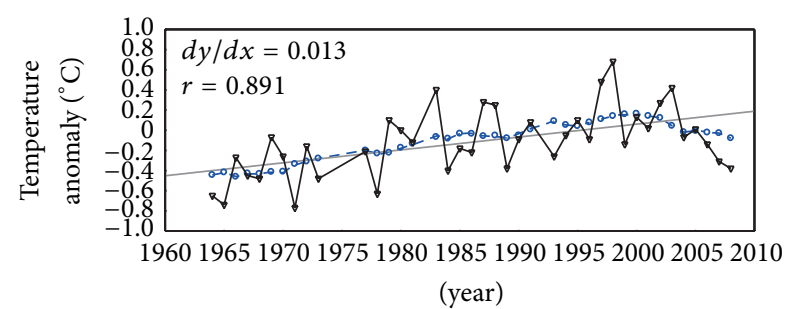

$\rightarrow$ Mean temperature $\quad-$ Fitted line
$-\ominus-11$ pt soothed line $\quad--$ Standard deviation

(b)

Figure 7: (a) Yearly mean temperature along with standard deviation and (b) anomaly.

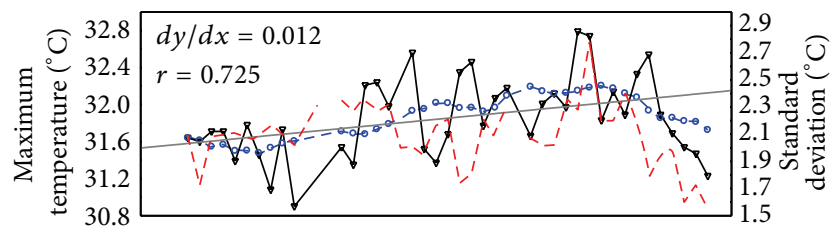

(a)

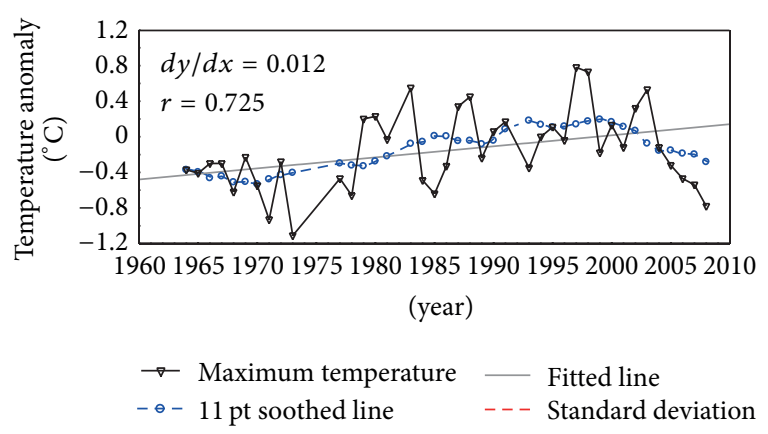

(b)

Figure 8: (a) Yearly mean maximum temperature along with standard deviation and (b) anomaly.

microphysical processes in mid-latitudes as in Minnis et al. [28], Zerefos et al. [29]. Eleftheratos et al. [30] have studied the variability of cirrus clouds over the tropics governed by the activity of El Nino Southern Oscillation, the Quasi Biennial Oscillation and solar activity. Possible radiation budget alterations, modifications at the time of occurrence of minimum and maximum temperatures are to be critically examined as a part of future investigations. Prominent two maxima (secondary maximum is very shallower compared to

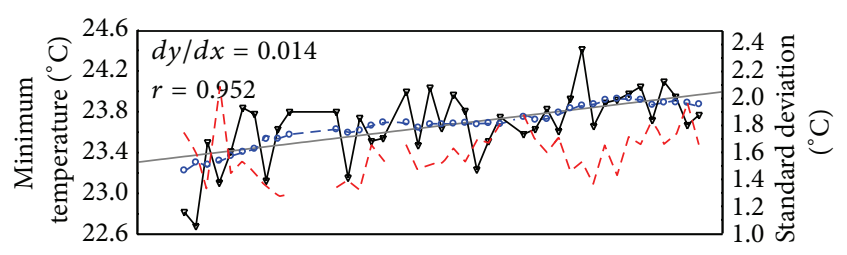

(a)

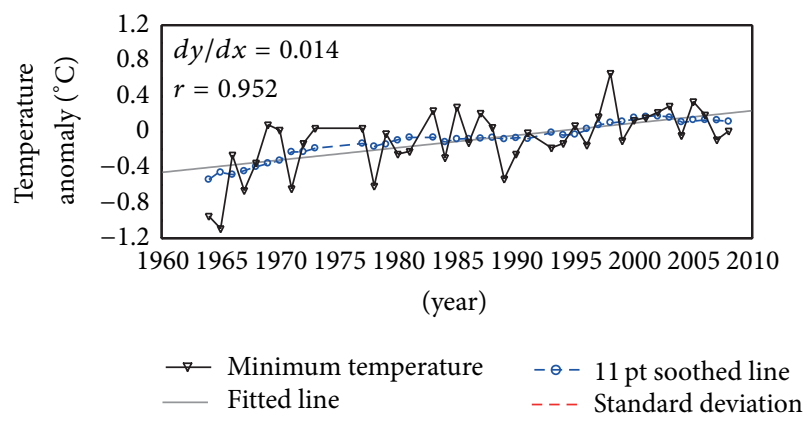

(b)

FIGURE 9: (a) Yearly mean minimum temperature along with standard deviation and (b) anomaly.

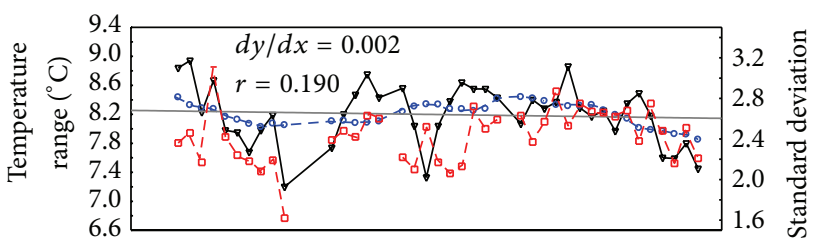

(a)

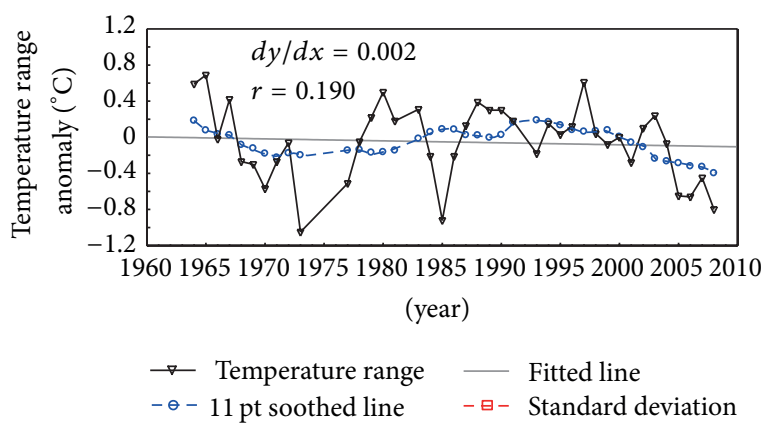

(b)

FIGURE 10: (a) Yearly mean temperature range along with standard deviation and (b) anomaly.

the primary) and two minima were seen in middle, high and total cloud climatology.

3.3. Mean Daily Climatology in Temperature. Mean of daily maximum, minimum, mean and range in temperature between daily maximum and minimum temperatures are computed and depicted for the 365 days in a year (Figures 2, 3, 4 and 5) along with their standard deviations. The increase in mean daily values in present data temperatures are quite obvious and standard deviation values are fallen within 


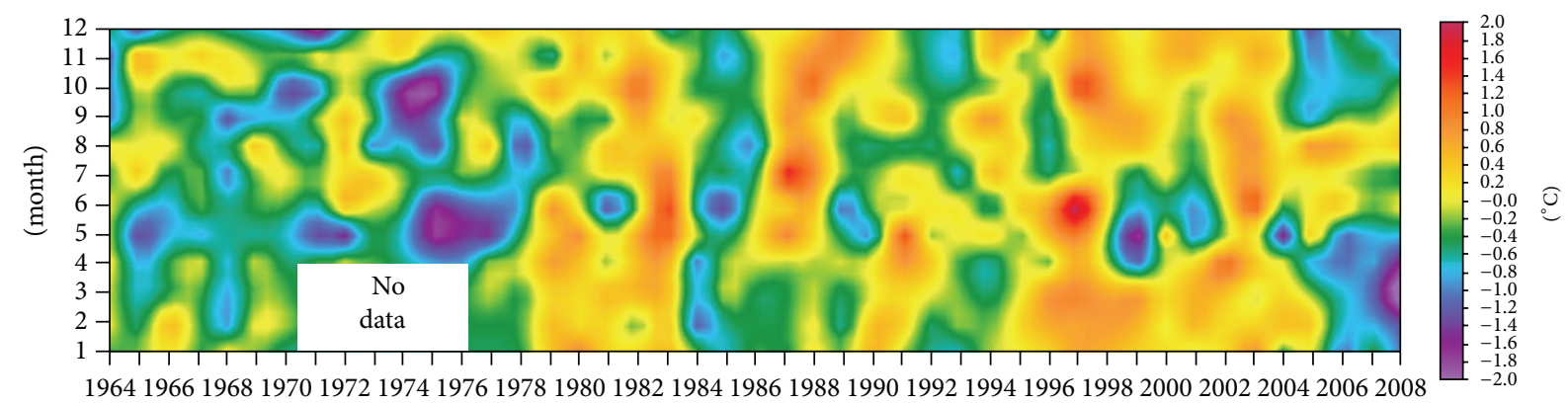

(year)

FIGURE 11: Maximum temperature anomaly.

$2.7^{\circ} \mathrm{C}$ for all the four mean daily climatologies. A difference statistics for 365 days between present data to past data is made and is shown in Figure 6. Out of 365 days, more than $80 \%$ mean daily maximum, minimum and mean temperatures are distributed as greater than zero occurrences in the difference statistics. An elevated frequency of occurrence of more than $65 \%$ under less than zero class is a concrete feature which implies that the range among maximum and minimum temperature is alarmingly diminishing.

3.4. Interannual Variability. Inter annual variability has critically examined for annual mean of minimum, maximum and mean temperatures, annual rainfall in the SW and NE monsoon over the station and for the Kerala State and average annual surface pressure in the SW and NE monsoons for the station. Each inter annual variability data has undergone an 11 year moving average with end point extrapolation till the raw data availability to bring out long term trend and the trend line also has shown in each inter annual variability figures similar to Krishnakumar et al. [22] for the interannual variability of rainfall over Kerala. Interpolated values are obtained for each year from the trend and such a data set obtained, has been subjected to statistical significant test. interpolated data has not taken for a particular year, if the raw data point is missing for the corresponding year. This method has enabled no reduction in the degrees of freedom $(d f)$. To confirm the statistical significance on various 11 year moving averaged data and also to assess the strength of sample correlation coefficient $(r)$, linear regression $t$-test were carried out and the results are presented (Table 6). Generally strong and significant linear trend variations are observed. Even though linear trends of maximum and minimum temperatures have shown strong and significant statistical trends, the derived variable-temperature range has resulted a weak and insignificant test statistic. This may be statistically inferred as a variable derived out of two variables which favours strong and significant test statistic separately need not show the same test static of strong and significant.

3.4.1. Interannual Variability in Temperature. To assess the interannual variability with temperature, annual mean minimum, mean maximum and mean of mean temperatures are found out for each year from 1964 to 2008. Also to ascertain deviation from the normal, each yearly mean value is deducted from the mean of the entire values available for present data and thereby extracted the anomaly in temperature. Mean and standard deviation of daily mean, maximum, minimum and daily temperature range are computed for a year and depicted in Figures 7, 8, 9 and 10. The fitted linear trend line slope $(d y / d x)$ as well as correlation coefficient $(r)$ values are annotated in graphs. It is seen that from both mean daily temperature as well as from the maximum temperature an abrupt prominent shift or a discernible upward trend is occurred after 1976 may be like the "climate shift" as stated by Trenberth [24]. The 45 year rate in mean daily, maximum and minimum are obtained as $+0.585^{\circ} \mathrm{C},+0.540^{\circ} \mathrm{C}$ and $+0.630^{\circ} \mathrm{C}$ respectively or with decadal rates of $(+0.13 \pm$ $0.01)^{\circ} \mathrm{C},(+0.12 \pm 0.02)^{\circ} \mathrm{C}$ and $(+0.14 \pm 0.0)^{\circ} \mathrm{C}$ accordingly. In the obtained value for the global mean surface temperature as a whole $(+0.07 \pm 0.02)^{\circ} \mathrm{C}$, surface temperatures over land have risen at about double the ocean rate after 1979 (more than $(+0.27 \pm 0.06)^{\circ} \mathrm{C}$ per decade versus $(+0.13 \pm 0.04)^{\circ} \mathrm{C}$ per decade) as per the Trenberth et al. [31]. From 1950 to 2004 , the global land trend in diurnal temperature range was extracted as negative $\left(-0.07^{\circ} \mathrm{C}\right.$ per decade) although tropical areas are still underrepresented [31]. Kumar et al. [32] showed trends of increase in diurnal temperature range, significant increase in annual maximum temperature, and practically trendless annual minimum temperature over India in the last century. Our inter annual variability results coincide mostly with former studied data period which supports the decrease of diurnal temperature range, and the same is very vivid from Figure 6 discussed earlier. It infers that for this tropical coastal station the obtained decadal rate of $(+0.130 \pm$ $0.01)^{\circ} \mathrm{C}$, which is in agreement with global ocean rate, may be due to the station being coastal in origin. The error value reduction by $\pm 0.03^{\circ} \mathrm{C}$ for TERLS can be due to more stabilized single station data. Also rate of increase in trend for minimum temperature is high in comparison to maximum temperature. A decreasing trend in maximum temperature is noticed after 2005 with decreasing standard deviation values. This observation might be correct as a result of shifting the observatory since 1964 to hardly $30 \mathrm{~m}$ towards north in 2005 were smooth and free sea-breeze flow which enables abrupt reach of maximum temperature in the diurnal course around the time of sea breeze onset. The feature of attaining the maximum temperature of the day around the time of onset of 
TABLE 6: Linear trends of 11 year moving averaged data on various inter-annual variability. Level of significance was choosen at $0.05 \%$ to read out critical $t$ values $\left(t_{c}\right)$ corresponding to the degree of freedom $(d f)$. If $r>0.5$ strong, $r<0.5$ weak, $t>t_{c}$ significant, and $t<t_{c}$ not significant.

\begin{tabular}{|c|c|c|c|c|c|c|c|}
\hline No. & $\begin{array}{c}\text { Interannual } \\
\text { variability in }\end{array}$ & $r$ & $\begin{array}{c}\text { Slope }(d y / d x) \pm \\
\text { error }\end{array}$ & Calculated $t$ & $d f$ & Comments & Data missing \\
\hline 1 & Mean temperature & 0.891 & $0.013 \pm 0.001$ & 12.08154 & 38 & $\begin{array}{c}\text { Strong and } \\
\text { significant. (Figures } \\
7(\mathrm{a}) \text { and } 7(\mathrm{~b}))\end{array}$ & $\begin{array}{r}1974,1975,1976 \\
1982 \text {, and } 1992\end{array}$ \\
\hline 2 & $\begin{array}{l}\text { Mean maximum } \\
\text { temperature }\end{array}$ & 0.725 & $0.0121 \pm 0.002$ & 6.50392 & 38 & $\begin{array}{c}\text { Strong and } \\
\text { significant. } \\
\text { (Figures } 8(\mathrm{a}) \text { and } 8(\mathrm{~b})\end{array}$ & $\begin{array}{r}1974,1975,1976 \\
1982 \text {, and } 1992\end{array}$ \\
\hline 3 & $\begin{array}{l}\text { Mean minimum } \\
\text { temperature }\end{array}$ & 0.952 & $0.014 \pm 0.000$ & 19.29677 & 38 & $\begin{array}{c}\text { Strong and } \\
\text { significant. } \\
\text { (Figures 9(a) and } \\
9(\mathrm{~b}))\end{array}$ & $\begin{array}{r}1974,1975,1976 \\
1982 \text {, and } 1992\end{array}$ \\
\hline 4 & $\begin{array}{c}\text { Mean temperature } \\
\text { range }\end{array}$ & -0.190 & $-0.002 \pm 0.002$ & -1.19078 & 38 & $\begin{array}{l}\text { Weak and not } \\
\text { significant } \\
\text { (Figure } 10(a)) .\end{array}$ & $\begin{array}{r}1974,1975,1976 \\
1982, \text { and } 1992\end{array}$ \\
\hline 5 & $\begin{array}{l}\text { South West } \\
\text { monsoon rainfall } \\
\text { (Thumba) }\end{array}$ & -0.477 & $-2.145 \pm 0.616$ & -3.483 & 41 & $\begin{array}{c}\text { Weak and significant } \\
\text { (Figure 14) }\end{array}$ & 1964,1998 \\
\hline 6 & $\begin{array}{l}\text { North East } \\
\text { monsoon rainfall } \\
\text { (Thumba) }\end{array}$ & 0.848 & $3.928 \pm 0.393$ & 10.000 & 39 & $\begin{array}{c}\text { Strong and significant } \\
\text { (Figure 15) }\end{array}$ & $\begin{array}{c}1964,1977,1992 \\
\text { and } 1998\end{array}$ \\
\hline 7 & $\begin{array}{c}\text { South West } \\
\text { monsoon rainfall } \\
\text { (Kerala) }\end{array}$ & -0.721 & $-6.149 \pm 0.934$ & -6.587 & 40 & $\begin{array}{l}\text { Strong and significant } \\
\text { (Figure 16) }\end{array}$ & $\begin{array}{c}1964,2007 \text {, and } \\
2008\end{array}$ \\
\hline 8 & $\begin{array}{c}\text { North East } \\
\text { monsoon rainfall } \\
\text { (Kerala) }\end{array}$ & 0.737 & $3.430 \pm 0.491$ & 6.986 & 41 & $\begin{array}{l}\text { Strong and significant } \\
\text { (Figure 17) }\end{array}$ & 1964,2008 \\
\hline 9 & $\begin{array}{c}\text { South West } \\
\text { monsoon surface } \\
\text { pressure }\end{array}$ & 0.445 & $0.006 \pm 0.002$ & 2.899 & 34 & $\begin{array}{c}\text { Weak and significant } \\
\text { (Figure 18) }\end{array}$ & 1964 to 1972 \\
\hline 10 & $\begin{array}{c}\text { North East } \\
\text { monsoon surface } \\
\text { pressure }\end{array}$ & -0.616 & $0.010 \pm 0.002$ & -4.555 & 34 & $\begin{array}{c}\text { Strong and significant } \\
\text { (Figure 19) }\end{array}$ & 1964 to 1972 \\
\hline
\end{tabular}

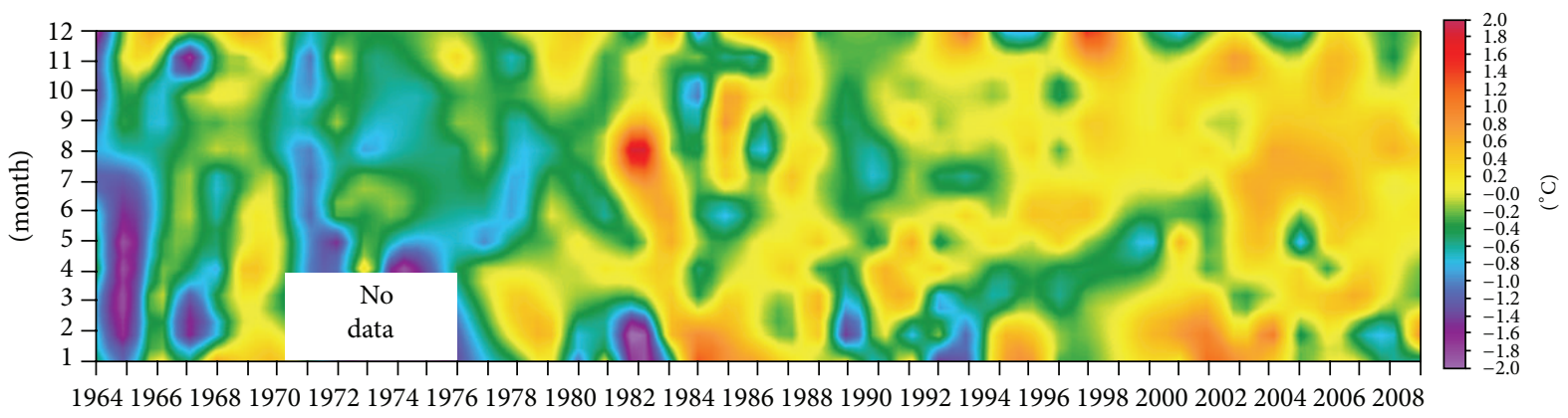

FIGURE 12: Minimum temperature anomaly.

sea breeze is known [33]. As the station is of coastal in origin, the occurrence of daily maximum temperature is very much linked to the setting and strong establishment of sea breeze front towards the land areas.

Mean monthly anomaly structures in minimum, maximum, and mean temperatures are presented in time section contour diagrams (Figures 11, 12 and 13). All contour depictions show well-marked temperature increase during the course of years and are so pronounced after 1976.

3.4.2. Interannual Variability in SW and NE Monsoon Rainfall and Surface Pressure. Interannual variability in rainfall and surface pressure particularly for SW monsoon and NE monsoon are studied. A decrease in trend in SW monsoon 


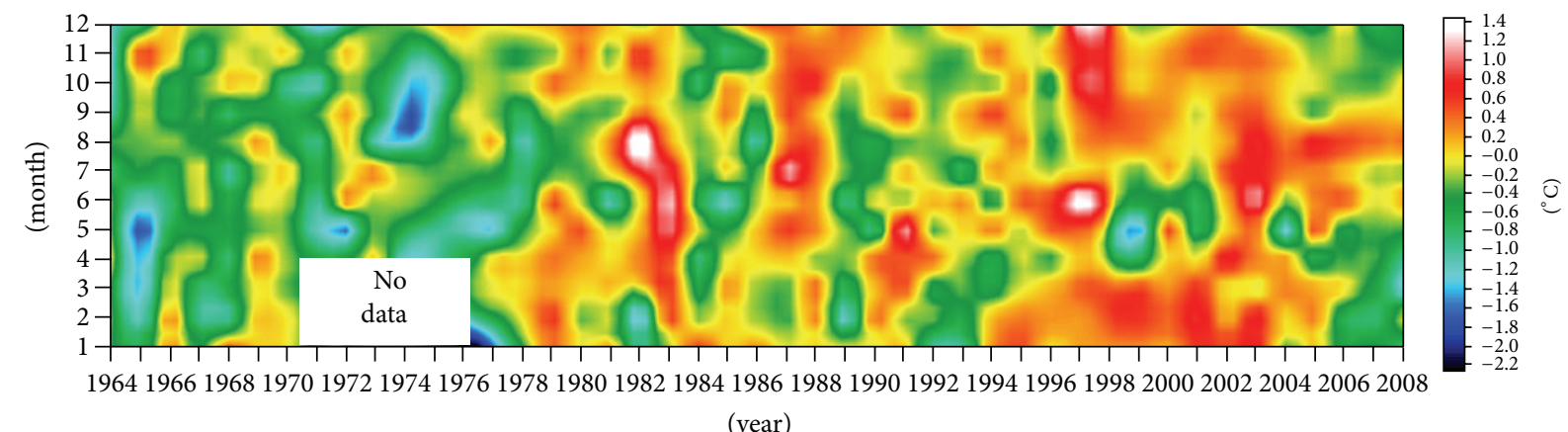

FIGURE 13: Mean temperature anomaly.

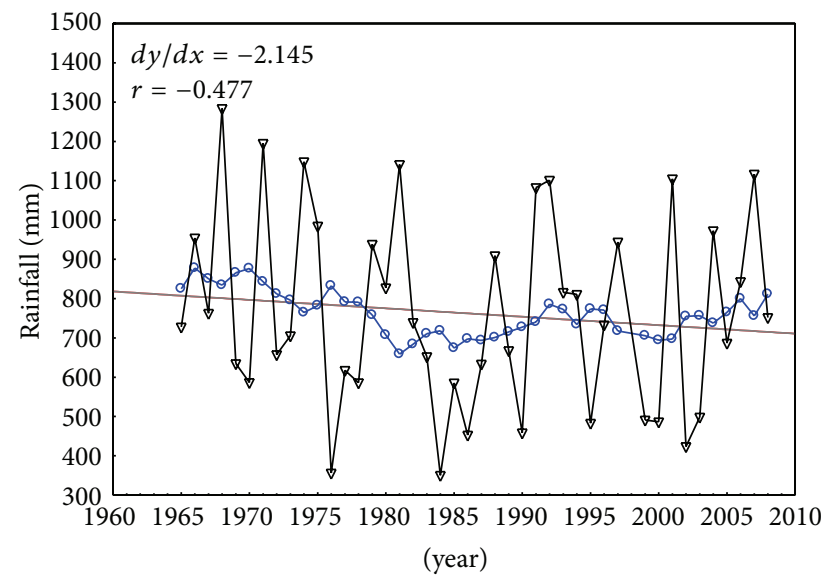

FIgURE 14: South West monsoon rainfall over Thumba.

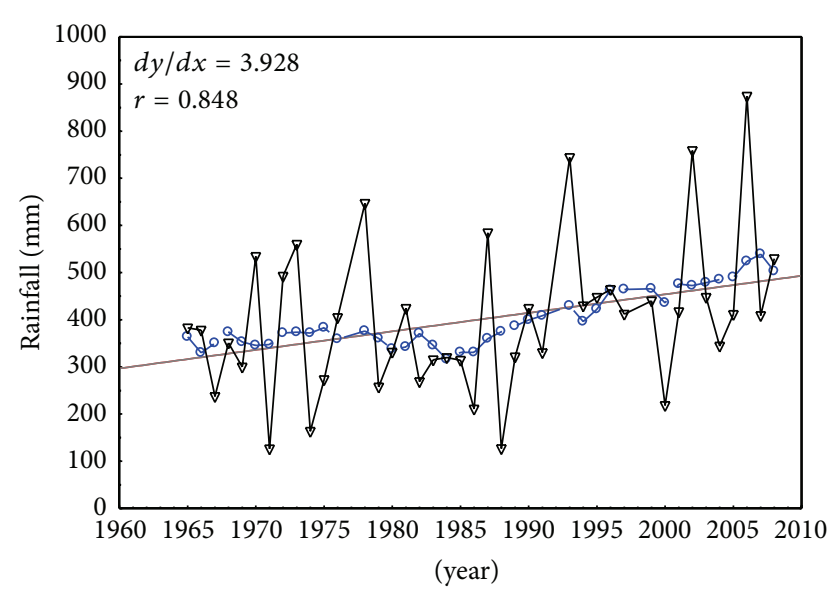

FIgURE 15: North East monsoon rainfall over Thumba.

and an increase in trend in NE monsoons are the observed features over the station with decadal variability of $(-21.5 \pm$ $6.2) \mathrm{mm}$ and $(+39.3 \pm 3.9) \mathrm{mm}$, respectively (Figures 14 and 15). Analysis by considering initial rainfall values (at the beginning year on the fitted straight line) of South West monsoon, North East monsoon, corresponding slope of them as $817.822 \mathrm{~mm}, 296.535 \mathrm{~mm},-21.5 \mathrm{~mm} /$ decade and

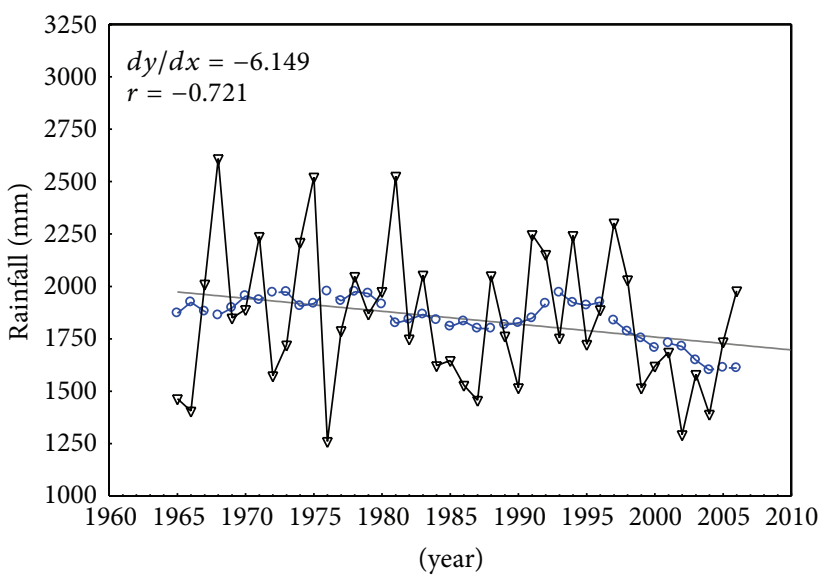

FIGURE 16: South West monsoon rainfall over Kerala.

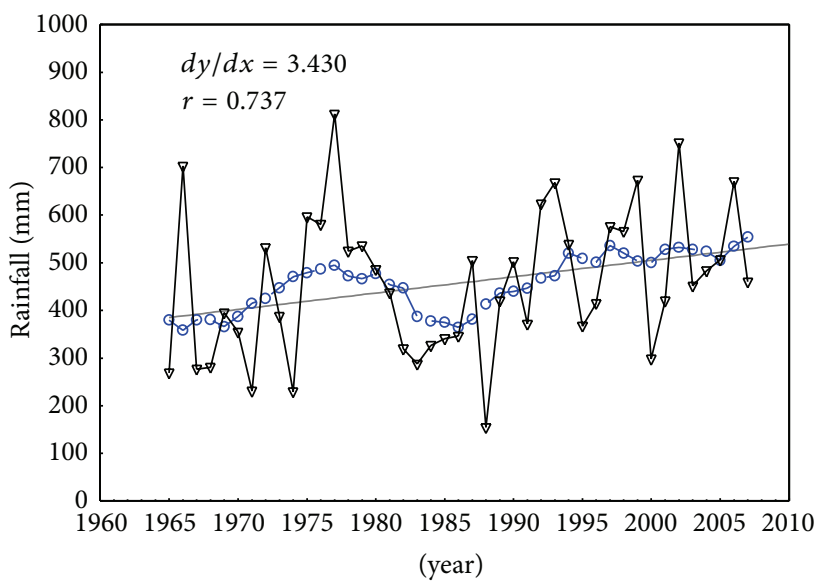

FIGURE 17: North East monsoon rainfall over Kerala.

$39.3 \mathrm{~mm} /$ decade, respectively, shows the likelihood exceed of North East monsoon rainfall over South West monsoon over this region after the year 2050 if the current trend continues. Similar analyses are carried out on the slot 1965 to 2007 for the Kerala meteorological subdivision from the longest instrumental rainfall series of the Indian regions (1813-2006) ([34]; http://www.tropmet.res.in/). The actual rainfall amount over Kerala during 2007 is obtained from the 


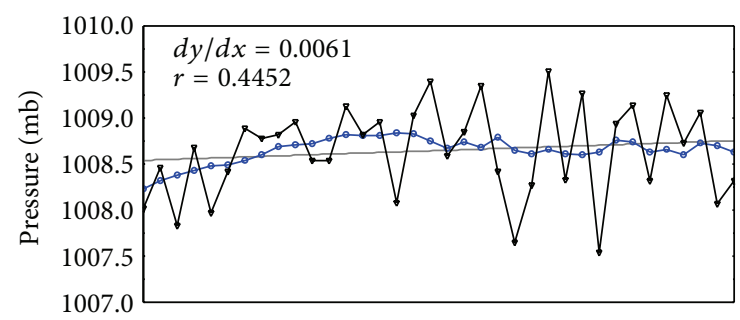

(a)

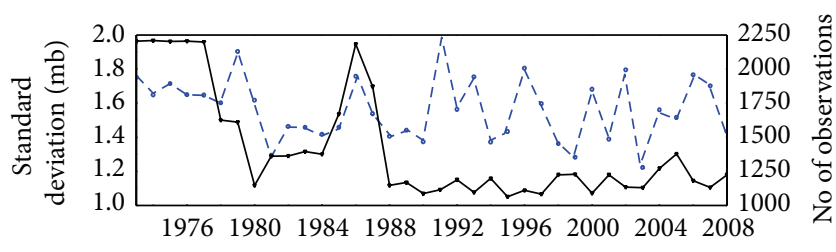

(year)

- $\bullet$ - Standard deviation

$\rightarrow$ Number of observations

(b)

FIGURE 18: (a) Interannual variability in surface pressure for South West monsoon season along with (b) standard deviation and number of observations.

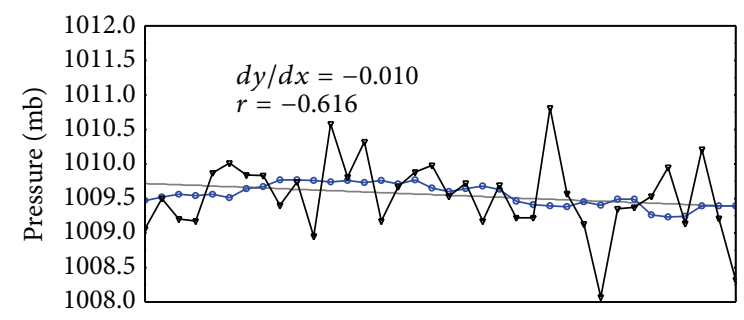

(a)

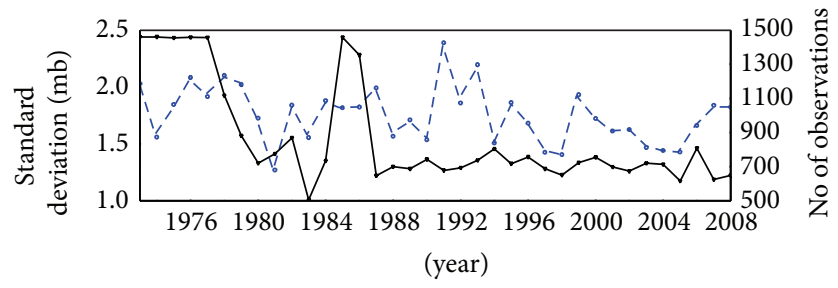

- $\theta$ - Standard deviation

$\rightarrow$ No of observations

(b)

FIGURE 19: (a) Interannual variability in surface pressure for North East monsoon season along with (b) standard deviation and number of observations.

quarterly journal the MAUSAM (July 2008 and October 2008 issues). Decadal variations show a decreasing trend in SW monsoon by $(-61.5 \pm 9.3) \mathrm{mm}$ and increasing trend in NE monsoon by $(+34.0 \pm 4.9) \mathrm{mm}$ (Figures 16 and 17).

Interannual variability in surface pressure was derived and depicted for SW monsoon (Figure 18) and NE monsoon (Figure 19). For this, every hourly data available since 1973 was subjected to mean monthly value computation. Number of observations available ranges from 1100 to 2245 in SW monsoon and 500 to 1495 in NE monsoon, respectively, and provided along with the standard deviation values in the above figures. Since atmospheric pressure is a highly stabilized property over a region for a particular season, the decadal trend variability observed is $(+0.06 \pm 0.02) \mathrm{mb}$ and $(-0.10 \pm 0.02) \mathrm{mb}$ for SW monsoon and NE monsoon, respectively. The positive (increase) and negative (decrease) interannual trends observed in SW monsoon and NE monsoon, respectively, might have contributed possible implications in the development of associated synoptic scale meteorological systems (position and orientation of troughs/ridges and low pressures) and thereby corresponding decrease and increase in SW monsoon and NE monsoon rainfall trends.

\section{Conclusion}

Long-term surface meteorological records from TERLS were collected and analysed to study the long-term changes in overall climatology, climatology pertained to a particular time of observation, mean daily climatology in temperature, interannual variability in temperature, interannual variability in SW and NE monsoon rainfall, and mean monthly anomaly structure in temperature. Results on various analyses show strong and vivid features contributed by climate change. The salient features observed contributed by climate change are as follows:

(1) All the temperatures show increase in their behaviour with slight decrease in $\mathrm{RH}$ between the present climatology and past climatology.

(2) Steadiness of wind decreases especially in non-SW monsoon months, which gives an indirect signature of possible modifications in meso-scale systems.

(3) High cloud climatology increases and thereby probable modifications in radiation budget, time of occurrence of maximum and minimum temperatures.

(4) Daily statistics for 365 days show more than $80 \%$ exceedance in present climatology in comparison to past in minimum, maximum, and mean temperature.

(5) Interannual variability analysis in mean temperature for this tropical coastal station shows $+1.3^{\circ} \mathrm{C} / 100$ years which is same as that of global ocean rate.

(6) Observed interannual rainfall variability in SW monsoon and North East monsoon shows decrease in trend by $-21.45 \mathrm{~mm} /$ decade and increase in trend by $+39.3 \mathrm{~mm} /$ decade, respectively. Prognosis on this observation points out the likelihood exceedance of NE monsoon rainfall over the South West monsoon after the year 2050 for the station. But it is prejudicial to infer that the rainfall increase in NE monsoon can compensate the forecasted decrease in SW monsoon, since NE monsoon is mostly of heavy rainfall in nature as a result of meso-scale convective systems. Such rainfall runoff is very fast than the slow water infiltration feature in association with SW monsoon 
rainfall, which is essential for irrigation and agricultural needs.

(7) Decadal variability in surface pressure has shown $+0.06 \mathrm{mb}$ and $-0.10 \mathrm{mb}$ for $\mathrm{SW}$ monsoon and $\mathrm{NE}$ monsoon, respectively.

The imprints due to climate change on various meteorological parameters over this coastal station proved that the region also faces vulnerable situation due to the phenomena, and therefore, necessary engineering methods/socioeconomic steps are to be undertaken.

\section{Acknowledgments}

The availability of this unique data for a continuous period of 45 years is the outcome of concerted and whole hearted efforts put in by the staffs of TERLS/India Meteorological Department. It is a pleasure to acknowledge with esteemed gratitude the team that worked since 1963 at the TERLS, Thumba, whose efforts have yielded the voluminous unique data bank which is available for investigations. The authors are extremely grateful to Dr. K Krishnamoorthy, Director, Space Physics Laboratory, VSSC, and the reviewers for their valuable comments that helped to improve the paper to the final form.

\section{References}

[1] N. Oreskes, "The scientific consensus on climatic change," Science, vol. 306, p. 1686, 2004.

[2] H. Ayyar, Effect of Pollution on Weather. Science Reporter. Council of Scientific and Industrial Research (CSIR), 1973.

[3] K. Rupa Kumar, A. K. Sahai, K. Krishna Kumar et al., "Highresolution climate change scenarios for India for the 21st century," Current Science, vol. 90, no. 3, pp. 334-345, 2006.

[4] P. Brohan, J. J. Kennedy, I. Harris, S. F. B. Tett, and P. D. Jones, "Uncertainty estimates in regional and global observed temperature changes: a new data set from 1850," Journal of Geophysical Research D, vol. 111, no. 12, Article ID D12106, 2006.

[5] T. M. Smith and R. W. Reynolds, "A global merged landair-sea surface temperature reconstruction based on historical observations (1880-1997)," Journal of Climate, vol. 18, no. 12, pp. 2021-2036, 2005.

[6] K. M. Lugina, P. Y. Groisman, K. Y. Vinnikov, V. V. Koknaeva, and N. A. Speranskaya, "Monthly surface air temperature time series area-averaged over the 30-degree latitudinal belts of the globe, 1881-2004 In Trends: a compendium of data on global change," Carbon Dioxide Information Analysis Centre, Oak Ridge National Laboratory, US Department of Energy, Oak Ridge, Tenn, USA, 2005, http://cdiac.esd.ornl.gov/trends/temp/ lugina/lugina.html.

[7] J. Hansen, R. Ruedy, M. Sato et al., "A closer look at United States and global surface temperature change," Journal of Geophysical Research D, vol. 106, no. 20, pp. 23947-23963, 2001.

[8] S. Solomon, D. Quin, M. Manning et al., "Contribution of working group I to the Fourth Assessment Report of the IPCC," Tech. Rep. IPCC-AR4, 2007.

[9] R. C. Balling Jr. and S. W. Brazel, "Recent changes in Phoenix, Arizona summertime diurnal precipitation patterns," Theoretical and Applied Climatology, vol. 38, no. 1, pp. 50-54, 1987.
[10] R. Bornstein and Q. Lin, "Urban heat islands and summertime convective thunderstorms in Atlanta: three case studies," Atmospheric Environment, vol. 34, no. 3, pp. 507-516, 2000.

[11] P. G. Dixon and T. L. Mote, "Patterns and cause of Atlanda's urban heat island-initiated precipitation," Journal of Applied Meteorology, vol. 42, pp. 1273-1284, 2003.

[12] F. Fujibe, "Long-term surface wind changes in the Tokyo metropolitan area in the afternoon of sunny days in the warm season," Journal of the Meteorological Society of Japan, vol. 81, no. 1, pp. 141-149, 2003.

[13] T. Inoue and F. Kimura, "Urban effects on low-level clouds around the Tokyo metropolitan area on clear summer days," Geophysical Research Letters, vol. 31, no. 5, Article ID L05103, 2004.

[14] J. M. Shepherd, H. Pierce, and A. J. Negri, "Rainfall modification by major urban areas: observations from spaceborne rain radar on the TRMM satellite," Journal of Applied Meteorology, vol. 41, no. 7, pp. 689-701, 2002.

[15] C. Price, S. Michaelides, S. Pashiardis, and P. Alpert, "Long term changes in diurnal temperature range in Cyprus," Atmospheric Research, vol. 51, no. 2, pp. 85-98, 1999.

[16] H. N. Singh, S. D. Patil, S. D. Bansod, and N. Singh, "Seasonal variability in mean sea level pressure extremes over the Indian region," Atmospheric Research, vol. 101, no. 1-2, pp. 102-111, 2011.

[17] J. Kingwell, J. Shimizu, K. Narita, H. Kawabata, and I. Shimizu, "Weather factors affecting rocket operations: a review and case history," American Meteorological Society, vol. 72, pp. 778-793, 1991.

[18] R. E. Turner and C. K. Hill, Terrestrial Environment (Climatic) Guidlines for Use in Aerospace Vehicle Development, 1982 Revision, Technical Memor. 82473, National Aeronautics and Space Administration, 1982.

[19] "Space Research in India," in Proceedings of the 38th COSPAR Meeting, pp. 199-204, Bremen, Germeny, 2010.

[20] P. V. Joseph and A. Simon, "Weakening trend of the southwest monsoon current through peninsular India from 1950 to the present," Current Science, vol. 89, no. 4, pp. 687-694, 2005.

[21] S. K. Dash, J. R. Kumar, and M. S. Shekhar, "On the decreasing frequency of monsoon depressions over the Indian region," Current Science, vol. 86, no. 10, pp. 1404-1411, 2004.

[22] K. N. Krishnakumar, G. S. L. H. V. Prasada Rao, and C. S. Gopakumar, "Rainfall trends in twentieth century over Kerala, India," Atmospheric Environment, vol. 43, no. 11, pp. 1940-1944, 2009.

[23] National Council of Educational Research and Training (NCERT), India, Text book of physics-part I for class 11, 2006.

[24] K. E. Trenberth, "Recent observed interdecadal climate changes in the Northern Hemisphere," Bulletin of the American Meteorological Society, vol. 71, no. 7, pp. 988-993, 1990.

[25] T. K. Karl, H. F. Diaz, and G. Kukla, "Urbanization: its detection and effect in the United States climate record," Journal of Climate, vol. 1, pp. 1099-1123, 1988.

[26] M. Rebetez and M. Beniston, "Changes in sunshine duration are correlated with changes in daily temperature range this century: an analysis of Swiss climatological data," Geophysical Research Letters, vol. 25, no. 19, pp. 3611-3613, 1998.

[27] K. V. S. Namboodiri, P. K. Dileep, and K. Mammen, "Wind steadiness up to $35 \mathrm{~km}$ and its variability before the South West Monsoon onset and the withdrawal," Mausam, vol. 63, pp. 275282, 2012. 
[28] P. Minnis, A. J. Kirk, P. Rabindra, and P. Dung, "Contrails, cirrus trends, and climate," Journal of Climate, vol. 17, pp. 1671-1685, 2004.

[29] C. S. Zerefos, K. Eleftheratos, D. S. Balis, P. Zanis, G. Tselioudis, and C. Meleti, "Evidence of impact of aviation on cirrus cloud formation," Atmospheric Chemistry and Physics, vol. 3, no. 5, pp. 1633-1644, 2003.

[30] K. Eleftheratos, C. S. Zerefos, C. Varotsos, and I. Kapsomenakis, "Interannual variability of cirrus clouds in the tropics in el niño southern oscillation (ENSO) regions based on international satellite cloud climatology project (ISCCP) satellite data," International Journal of Remote Sensing, vol. 32, no. 21, pp. 63956405, 2011.

[31] K. E. Trenberth, P. D. Jones, and P. Ambenje, "Observations: surface and climate change," in Climate Change 2007: The Physical Science Basis. Contribution of working group I to the Fourth Assessment Report of the Intergovernmental Panel on Climate Change, S. Solomon, D. Qin, and M. Manning, Eds., Cambridge University Press, Cambridge, UK, 2007.

[32] K. R. Kumar, K. K. Kumar, and G. B. Pant, "Diurnal asymmetry of surface temperature trends over India," Geophysical Research Letters, vol. 21, no. 8, pp. 677-680, 1994.

[33] T. R. Sivaramakrishnan and P. S. Prakash Rao, "Sea-breeze features over Sriharikota, India," Meteorological Magazine, vol. 118, no. 1400, pp. 64-67, 1989.

[34] N. A. Sontakke, N. Singh, and H. N. Singh, "Instrumental period rainfall series of the Indian region (AD 1813-2005): revised reconstruction, update and analysis," Holocene, vol. 18, no. 7, pp. 1055-1066, 2008. 

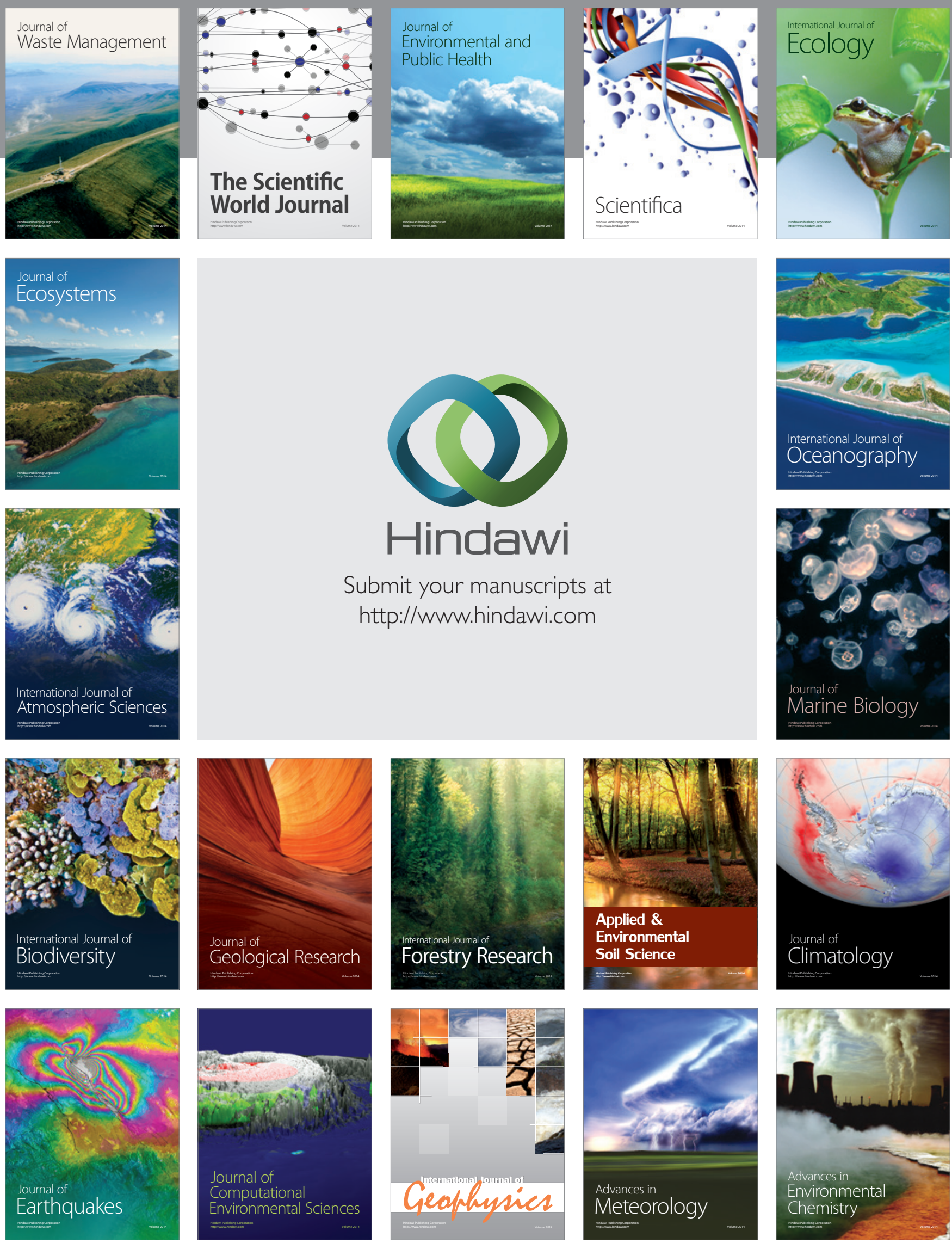